\title{
Experience of the Reliability of Intraoperative Sampling of Tissue PTH in Parathyroid Surgery: Letter to the Editor
}

\author{
James Kirkby-Bott • Bruno Carnaille
}

Published online: 1 May 2010

(C) Société Internationale de Chirurgie 2010

We congratulate Horányi et al. [1] on their work using parathyroid hormone (PTH) tissue aspirates to confirm tissue as being parathyroid in origin. Theirs is the largest reported series out of the four series published [1-4]. We have also been using a similar technique over the past 15 months and have collected 248 samples that have been validated by comparing biochemical results with fixed specimen histopathology results. Our results are due to be presented at the ESES meeting in Vienna in May. Our results look very much like Horányi et al.'s with a $100 \%$ specificity achievable. However, we had four false-negative results from an inadequate first sample; repeat sampling confirmed their true nature. Because of this, the PTH level we needed to confirm parathyroid tissue origin at a $100 \%$ specificity was substantially higher at $1168 \mathrm{pg} / \mathrm{ml}$. We constructed a ROC curve for the test (Table 1), the results of which were very encouraging: At a PTH level of $403 \mathrm{pg} / \mathrm{ml}$, a sensitivity of $97.62 \%$ and specificity of 98.04\% were achieved. Our sampling technique was slightly different and we are not sure if this may have accounted for the difference in sampling results. We used a smaller needle (23 gauge) and diluted the tissue in the hub of the needle to $2 \mathrm{ml}$ of saline before placing the sample in an EDTA serum sample bottle to send to the lab as if it were a blood sample for intact PTH analysis. We used the standard assay and not the "quick assay" reading. We also

J. Kirkby-Bott $(\bowtie) \cdot$ B. Carnaille

Department of General and Endocrine Surgery, Hôpital Claude

Huriez, Lille Cedex 59037, France

e-mail: james.kirkby1@mac.com

B. Carnaille

Chirurgie générale et endocrinienne, CHRU - Hopital Claude

Huriez Centre Médical, sur 2 Avenue Oscar Lambret,

Lille 59037, France
Table 1 ROC curve results

\begin{tabular}{ll}
\hline Area & 0.9981 \\
Std. Error & 0.0013 \\
$95 \%$ confidence interval & $0.9955-1.001$ \\
$p$ value & $<0.0001$
\end{tabular}

found a significant difference in abnormal and normal parathyroid tissue aspirates in primary hyperparathyroidism (HPT) (paired $t$ test, $p=0.011$ ). As many people also measure intraoperative PTH, we agree that this is an economic technique for confirming tissue origin rather than relying on frozen section.

\section{References}

1. Horányi J, Duffek L, Szlávik R et al (2010) Intraoperative determination of PTH concentrations in fine needle tissue aspirates to identify parathyroid tissue during parathyroidectomy. World $\mathrm{J}$ Surg 34:538-543

2. Chan RK, Ibrahim SI, Pil P et al (2005) Validation of a method to replace frozen section during parathyroid exploration by using the rapid parathyroid hormone assay on parathyroid aspirates. Arch Surg 140:371-373

3. Lo CY, Chan WF, Leung P et al (2005) Applicability of tissue aspirate for quick parathyroid hormone assay to confirm parathyroid tissue identity during parathyroidectomy for primary hyperparathyroidism. Arch Surg 140:146-149, discussion 150

4. Perrier ND, Ituarte P, Kikuchi S et al (2000) Intraoperative parathyroid aspiration and parathyroid hormone assay as an alternative to frozen section for tissue identification. World J Surg 24:1319-1322 